\author{
Elżbieta KOTKOWSKA \\ (Poznań, UAM)
}

\title{
NAUCZANIE ŚW. GRZEGORZA Z NYSSY O WSZECHMOCY BOŻEJ NA PODSTAWIE IN ILLUD: TUNC IPSE FILIUS
}

Współcześnie dużo bardziej niż w przeszłości człowiek ma dowody na to, że najmniejsze zmiany $w$ jednym punkcie ziemi mają wpływ na wydarzenia w zupełnie innym miejscu naszego globu ${ }^{1}$. Rozważania filozoficzne związane $\mathrm{z}$ uwzględnieniem ogółu relacji występujących w świecie znajdujemy w dociekaniach A.N. Whiteheada, który nawiązuje do myśli starożytnej Grecji, a szczególnie do filozofów przyrody ${ }^{2}$. W swojej filozofii rozumie on stworzenie jako jeden organizm, połączony wzajemnymi relacjami, a jego rozwój jako proces stawania się. Według filozofa proces ten nie ma swojego ostatecznego kresu. Whitehead lączy w jeden spójny system historię świata materialnego i duchowego. Na bazie jego filozofii powstała tzw. process theology. Uczeni opierający się na dociekaniach Whiteheada stwierdzają, że każdy byt jest konstytuowany przez ogół swych relacji ${ }^{3}$. Swiadomość istniejących powiązań i oddziaływań przeniesiona na grunt teologii musi rodzić pytania o relacje pomiędzy wolnością człowieka a jego relacją ze środowiskiem.

W historii myśli europejskiej są tacy teologowie i zarazem filozofowie, którzy w swoich dziełach prezentują zadziwiającą harmonię teologii i filozofii. W naszym przekonaniu można do nich również zaliczyć św. Grzegorza z Nyssy ${ }^{4}$,

${ }^{1}$ Zjawiska te, choć są powiązane, są często nieobliczalne, czyli nie można wyznaczyć algorytmu, który przy tych samych warunkach da zawsze ten sam wynik. Takimi zjawiskami zajmuje się matematyczna teoria chaosu. Jest w niej opisywany tzw. Efekt Motyla. W dużym uproszczeniu oznacza to, że bardzo mała przyczyna taka właśnie, jak zaburzenie ruchu powietrza przez poruszanie się skrzydel motyla na jednej pólkuli ziemskiej może spowodować bardzo duży skutek w koŕcowym efekcie np. tornado na drugiej półkuli. Por. http://www.calculemuorg/hayek/ Tekst.html [20. 03. 2002].

${ }^{2}$ Por. M. Heller, Wypisy z Whiteheada, w: M. Heller - J. Życiński, Wszechświat i filozofia, Kraków 1980, 101.

${ }^{3}$ Por. A.N. Whitehead, Process and reality, New York 1929; tenże, Science and the Modern World, New York 1967.

${ }^{4}$ Warto zaznaczyć, że w opracowaniach dotyczących historii filozofii św. Grzegorz jest umieszczany jako przedstawiciel filozofii immaterialistycznej. Mówi się o nim jako o prekursorze współczesnej krytyki pojęcia substancji, por. B.A.G. Fuller, Historia filozofii, thum. Cz. Znamierowski, II, 
jednego z wielkich Ojców Kapadockich, teologa, filozofa i mistyka. Patrzy on na świat i tworzy swoją teologię jakby z punktu widzenia samego Boga, a wiec jest ona przede wszystkim teocentryczna. Jednocześnie mocno podkreśla, że dostęp do Boga jest możliwy tylko poprzez Syna Bożego, stąd jego teologia jest jednocześnie chrystocentryczna. Grzegorz ma poczucie istniejących wzajemnych relacji zarówno w samym Bogu, jak i w Jego odniesieniu do stworzenia. Jego myśl jest wyrazem i pragnieniem syntezy, poprzez którą chce zobaczyć całość w nierozerwalnych związkach z Bogiem. Dzięki doświadczeniu mistycznemu patrzy na świat, a zarazem jakby poprzez świat. Można powiedzieć, że jego udziałem jest takie widzenie wszechświata, że poprzez niego dostrzega moc stwórczą Boga, czyli 'widzi' stworzenie jako istniejące dzięki mocy Boga. Stąd dla niego relacja laski, jaką Bóg udziela stworzeniu do indywidualnej wolności, realizującej się w człowieku, to nie jest problem władzy, ale jest to problem miłości. Chrześcijaństwo jest dla niego religią otwartej przyszłości bez determinizmu, predestynacji czy fatum, ponieważ wolność człowieka to realizująca się dynamiczna przestrzeń możliwości wyboru Boga, który sam jest darem.

Warto zauważyć i spróbować się zapoznać, jak z pełną mocą i świadomością ten Ojciec Kościoła, na bazie własnych doświadczeń mistycznych i wiedzy teologicznej, filozoficznej oraz współczesnych mu nauk przyrodniczych, ukazuje relację między wszechmocnym Bogiem a obdarzonym wolnością człowiekiem. Glos jego jest tym bardziej znaczący, że jest on teologiem z IV wieku, czyli z czasów niepodzielonego jeszcze Koscioła. Jego nauczanie, będące skarbcem Kościoła w tamtych czasach, we współczesnej teologii jest na nowo odkrywane ${ }^{5}$. Jego intuicje stają się inspiracją dla wielu nowych rozwiązań współczesnych problemów teologiczno-filozoficznych, związanych z szukaniem interpretacji dynamicznych relacji, jakie zachodzą pomiędzy zmiennym światem a niezmiennym Bogiem.

\section{OBRAZ BOGA}

Analizując dzieła św. Grzegorza z Nyssy, w pierwszym przybliżeniu możemy powiedzieć, że jest on typowym przedstawicielem swojej epoki ${ }^{6}$, w której bardziej podkreślano potęgę i moc Boga, jako absolutnego władcy niż tego,

\footnotetext{
Warszawa 1967, 145-156; J. Legowicz, Zarys historii filozofii. Elementy doksografii, Warszawa 1967, 357-360; W. Tatarkiewicz, Historia filozofii, I, Warszawa 1968, 206-208; A. Sparty, Dzieje filozofii starożytności chrześcijańskiej i średniowiecza, Poznań 1992, 35-36; H.A. Armstrong, The Theory of the Non-existence of Matter in Plotinus and the Cappadocians, StPatr 5 (1962) 427-429.

${ }^{5}$ Natomiast wielki wkład św. Grzegorz z Nyssy w rozwój teologii mistycznej (szczególnie średniowiecznej) zawsze byl doceniany.

${ }^{6}$ Por. T. Węclawski, Abba wobec Boga Ojca, Kraków 1999, 36-54.
} 
który króluje przez uniżenie. Warto jednakże zwrócić uwagę na niewielkie, polemiczne jego dzieło, w którym jego rozumienie wszechmocy Bożej otrzymuje głębszy, interesujący nas wymiar. Kapadocczyk komentuje w nim jeden

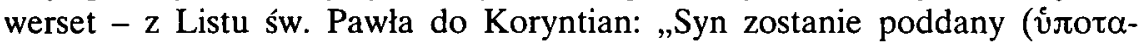
үท́бєtal) Temu, który Synowi podał wszystko, aby Bóg był wszystkim we wszystkich" (1Kor 15,28). Łaciński tytuł tego dzieła, nadany przez późniejszą tradycję, brzmi: In illud: "Tunc et ipse filius», etc. ${ }^{7}$. Problemem, jakim zajął się w nim Grzegorz, był błędny pogląd Ariusza i jego zwolenników: skoro Syn jest poddany Bogu na zasadzie stworzenia, to $w$ takim wypadku nie może być równy Bogu Ojcu i tym samym nie jest Bogiem. Jednym z koronnych argumentów, jakim się posługiwali arianie, były właśnie te słowa Apostoła z Listu do Koryntian (1Kor 15, 28). Natomiast Biskup Nyssy wykazuje, że właśnie ten cytat, $\mathrm{z}$ perspektywy historiozbawczej, podkreśla bóstwo Chrystusa. Ukazuje nam przy tym wcielonego Syna Bożego, jako tego który nie przestając być wszechmocnym w boskiej naturze, poddał siebie - w pełnej wolności - Ojcu w swej ludzkiej naturze ${ }^{8}$. Obraz Boga, jaki wyłania się z tego dzieła, pozwala na włączenie głosu Grzegorza we współczesną dyskusję na temat wszechmocy Boga i możliwej wolności człowieka.

Biskup Nyssy mówiąc o wszechmocy Boga przedstawia ją jako moc władnącą wszystkim ${ }^{9}$. Często moc Bożą przedstawia jako władzę, którą w jego czasach, określano jako królewską. Jednocześnie zdaje sobie sprawę, że jakiekolwiek przedstawienie działania Boga wobec wszechświata nie jest obrazem pełnym: natura Boga jest niepojęta $\mathrm{i}$ „przewyższa [...] poznanie badacza"10. Mimo to Grzegorz pragnie, na sposób ludzkị, zbliżyć się do poznania natury Boga. Zdaje sobie sprawę, że może tego dokonać tylko we współpracy z łaską Bożą. Jest to droga trudna, wymagająca zestawienia ze sobą często przeciwstawnych stanowisk, wynikających z przesłania biblijnego i dociekań filozoficz-

${ }^{7}$ Jego tekst zob. Gregorius Nyssenus, In illud: Tunc et ipse filius, w: Gregorii Nysseni Opera (dalej GNO), ed. J.K. Downing, vol. 3/2, Leiden 1986, 1-28 lub PG 44, 1304-1325, thum. (frag.) M. Stokowska, w: H. de. Lubac, Katolicyzm. Spoteczny aspekt dogmatu, Kraków 1961, 120-121; i thum. T. Szramka, w: G.A. Maloney, Chrystus Kosmiczny: od Pawta do Teilharda, Warszawa $1972,252-253$. Jeżeli nie zaznaczono inaczej, zamieszczone w artykule fragmenty tegoż utworu zostały przełożone przez autorkę.

${ }^{8}$ W czasach Grzegorza na ten fragment Pisma św. powoływali się arianie, podważając bóstwo Chrystusa. Nasz Biskup podaje własną interpretację tego tekstu, w której na podstawie słów św. Pawła wysnuwa wnioski o boskiej naturze Slowa i Ducha Świętego, por. J. Daniélou, L'Adversus Arium et Sabellium de saint Grégoire de Nysse, et l'origénisme Capadocien, RSR 54 (1966) 61-66. Wydaje się, że jeśli chodzi o nauczanie Ariusza i jego uczniów, jest to jeden ze skrajniejszych przykładów rozumienia wszechmocy Boga jako niezależnej od nikogo władzy. Przedstawiając w sposób schematyczny ich sposób myślenia można powiedzieć, że uznawali, iż to co jest poddane nie może być równe, stąd zaprzeczenie boskości Syna.

${ }^{9}$ Por. Oratio catechetica magna 4, PG 45, 20AB, thum. W. Kania, PSP 14, 134, lub T. Sinko, Nauka katechetyczna, w: Swięty Grzegorz z Nyssy, Wybór pism, Warszawa 1963, 65.

${ }^{10}$ Ad Eustathium, ed. F. Mueller, GNO 3/1, 10, tłum. T. Grodecki, ŹMT 21, 85. 
nych $^{11}$. Prawda o relacjach między Bogiem a światem stworzonym jest nam dostępna jako Tajemnica. Kapadocczyk podkreśla:

„my jedynie na sposób przypuszczeń wyciągamy wnioski na podstawie pojedynczych znaków o tym, co chce ujść naszemu poznaniu, musimy dać się prowadzić za rękę poprzez wielkie jej [Bożej Mocy] dzialania do zbadania boskiej natury"12.

Grzegorz przekonuje, że Bóg jest niewidzialny, a my poznajemy Go poprzez Jego dzieła na tyle, na ile pozwala nam się poznać. Pisze o Bogu jako tym, który „swą opatrznością ogarnia wszystko i przyszłość zna tak samo jak przeszłośc" "13. Zastanawiając się nad relacją Boga do stworzenia dodaje, że: „opatrzność i moc Boża objęły ( $\pi \varepsilon \varrho \iota \varepsilon i \lambda \eta \pi \tau \alpha)$ w pierwszym akcie stworzenia cały rodzaj ludzki"14. Analizując przedstawione cytaty w pierwszym przybliżeniu powstaje obraz Boga, który wiedzą uprzednią zna wszystko i niełatwo oprzeć się myśli, że w taki obraz Boga trudno włączyć ludzką wolność. Trzeba

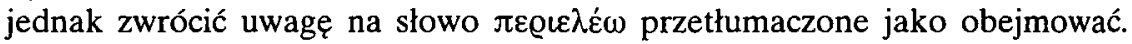
W rozumieniu Ojców Wschodu nie jest to tylko piękny zwrot. Bóg jako Ojciec właśnie swoją mocą obejmuje, czyli owija (zawija), przede wszystkim człowieka, a przez niego cały stworzony wszechświat. Tak „owinięty” wszechświat może zaistnieć, w innym przypadku po prostu by go nie było. Jest to podstawowe przekonanie $w$ rozważaniach o stworzeniu św. Grzegorza i Ojców Wschodu. Jeżeli mówią o wszechświecie, to zawsze jako o obdarowanym Bożą łaską. Całe dzieło Stwórcy, poznawane i doświadczane przez człowie$\mathrm{ka}$, jest Bożym królestwem, z którego „nic, co jest stworzone nie jest wyłączone"15. Stworzenie nie istnieje bez Bożej mocy, ale w niej i dzięki niej. Ojcowie Wschodu nie znają pojęcia natury czystej. Człowiek, a przez niego całe stworzenie, jeżeli istnieją, to tylko dzięki stworzeniu $\mathrm{w}$ łasce ${ }^{16} . \mathrm{Z}$ tego względu możemy w takim świecie i poprzez taki świat, poznać wszechmoc Boga samego.

Św. Grzegorz z Nyssy w swoim nauczaniu wyróżnia dwa sposoby mówienia o Bogu. Pierwszy $z$ nich odpowiada na pytanie: Kim jest Bóg?, i jest to dla niego dziedzina właściwa teologii - $\theta \varepsilon o \lambda o \gamma i \alpha$, natomiast dziedzina ekonomii -

${ }^{11}$ Przykładowo Grzegorz wobec sobie współczesnych czuje potrzebę wytłumaczenia, dlaczego Pismo św. przemawia w tak niejednoznacznym języku: „Pismo zna ludzi jak dobra mamka swoje dzieci i niekiedy gaworzy wraz z nimi i używa niektórych wyrażeń [niedokladnie], nie szkodząc przy tym temu, co doskonałe i nie wyrządzając szkody tym, którzy zdolni są przyjmować staly pokarm" (Ad Graecos 13, ed. F. Mueller, GNO 3/1, 27, thum. T. Grodecki, ŹMT 21, 98); por. też A. Grillmeier, Mit $\mathrm{Ihm}$ und in $\mathrm{lhm}$. Christologische Forschungen und Perspektiven, Freiburg 1975, 283-300, 423-488.

12 Ad Eustathium, GNO 3/1, 11, ŻMT 21, 85.

13 Oratio calechetica magna 8, PG 45, 37 BC, PSP 14, 80.

14 De hominis opificio 16, PG 44, 185B, thum. M. Michalski, ALP II 309.

15 In illud: Tunc ipse filius, GNO 3/2, 14, PG 44, 1313A.

${ }^{16}$ Por. R. Leys, L'image de Dieu chez saint Grégoire de Nysse, Bruxelles - Paris 1951, 98. 
oixovoui $\alpha^{17}$, jest próbą odpowiedzi na pytanie o możliwość poznania Boga poprzez Jego dzieła. Grzegorz szczególnie podkreśla w swoim nauczaniu, że Obraz Boga w Trójcy Jedynego i obraz Boga udzielającego się stworzeniu są obrazami wzajemnie zależnymi. Stając przed niepojmowalną Tajemnicą widział jedność i wzajemne oddziaływanie życia wewnętrznego Trójcy z Jej działaniem wobec stworzenia. Właśnie dlatego nasz Autor niewiele mówi o niezmiennym Bogu w Jego istocie i majestacie, a częściej o Bogu działającym dla swojego stworzenia. To jego przekonanie uwydatnia się w słowach, w których podkreśla jedność działania Trójcy:

„[...] wszelkie działanie (દ̉vé z wieloraką myślą (J 48) wychodzi od Ojca, przechodzi przez Syna i w Duchu Swiętym się doskonali [...] cokolwiek dzieje się, czy to dotyczące codziennej opatrzności czy też kierowania (ekonomią) i zachowania wszystkiego, dzieje się za sprawą trzech"18.

Każde działanie Boga jest działaniem Trzech w jedności z Nich wypływającej, jest jedno działanie i jeden Boży zamiar wobec stworzenia. Zawsze działa jeden Bóg, ale to działanie wynika $z$ dynamiki wewnętrznego życia Trójcy, w której jest ciągłe dążenie do jedności poprzez wzajemną wymianę chwały i miłości ${ }^{19}$.

\section{BÓG WOBEC STWORZEŃ}

1. Boże pragnienie jedności ze swoim stworzeniem. Zastanawiając się nad obrazem Boga, jaki wyłania się ze wspomnianego dzieła Grzegorza: In illud: Tunc et ipse filius, warto zwrócić uwagę, że nie neguje on dosłownej interpre-

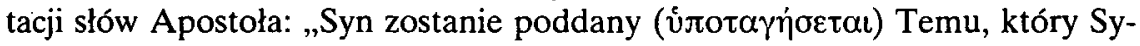
nowi podał wszystko, aby Bóg był wszystkim we wszystkich" (1Kor 15, 28), ale przenosi ją z płaszczyzny ontologicznej na historiozbawczą ${ }^{20}$. Punktem wyjścia

${ }^{17} \mathrm{~W}$ myśli Ojców Kościoła mówienie o wychodzącym ku czlowiekowi Bogu stanowiło dziedzinę ekonomii (oỉxovouía) w odróżnieniu od teologii ( $\theta \varepsilon o \lambda o \gamma i \alpha)$, która zajmowala się mówieniem o tajemnicy wewnętrznego życia Trójcy. Ojcowie Kapadoccy, a wśród nich szczególnie Grzegorz z Nyssy, rozwinęli rozumienie terminu ekonomia, który znaczy doslownie: budowanie domu, zarządzanie domem, rozdawanie, dysponowanie. Powiązali go z dzialaniem Trójcy Świętej wobec stworzenia, a działanie to rozumieli jako pedagogię Bożą. Tak więc stworzenie zawsze jest objęte pedagogiczną opieką Boga.

${ }^{18}$ Gregorius Nyssenus, Ad Ablabium, ed. F. Mueller, GNO 3/1, 47-48, thum. T. Grodecki, ŻMT 21, 111.

${ }^{19}$ Pomijamy tu polemikę związaną $z$ istnieniem w nauczaniu Grzegorza początków koncepcji wspólistnienia Hipostaz w Bogu. Na ten temat por. T. Grodecki, ŹMT 21, 31-37; D.F. Stramara, Gregory of Nyssa terminology for Trinitarian Perichoresis, VigChr 52 (1998) 257.

20 Podobnie postapil Grzegorz w interpretacji fragmentu Księgi Przysłów: „Pan mnie stworzyl" (Prz 8, 22), por. T. Grodecki, ŹMT 21, 41-42. 
jego rozważań, jest dzieło Syna Bożego, rozważane w perspektywie celu, do jakiego dąży całe stworzenie. Wymiar eschatologiczny teologii wypełnia całe nauczanie naszego Biskupa Nyssy, a w tym właśnie dziele w sposób szczególny dochodzi do glosu. Naucza on bowiem, że od Boga wszystko pochodzi i do Boga wszystko powróci dzięki dziełu Syna, które uobecnia działanie Ducha Świętego.

W swojej teologii Grzegorz z Nyssy na pierwsze miejsce wysuwa miłość, jako zasadę życia wewnętrznego Trójcy i miłość Boga do stworzeń, jako zasadę ich istnienia, podkreślając, że poznajemy ją w pełni nie inaczej, jak tylko dzięki Objawieniu Syna. Przekonanie to opiera na slowach Jezusa przekazanych przez Jana Ewangelistę: ,Ja kocham ich, jak Ty kochasz mnie” (J 17, 23) ${ }^{21}$. Syn kocha stworzenie, tak jak Ojciec kocha Syna. Tylko dzięki Synowi może człowiek tę miłość w pełni poznać, ponieważ to Syn Boży stał się człowiekiem i przez to w Nim się ta miłość objawia. Autor nasz stwierdza:

„On, zatem, który jest ponad wszelkim poznaniem i pojmowaniem, niewysłowiony (1P 1,8$)$, niewyrażalny i niewypowiedziany (2Kor 9,15$)$, z miłości do ludzi stał się obrazem Boga niewidzialnego"22.

W teologii Grzegorza jedynym więc i prawdziwym obrazem Boga jest Syn

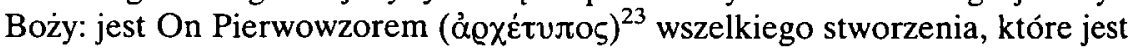
powołane do istnienia według tego obrazu. Mamy tu pewne stopniowanie podobieństwa do Boga. Należy zwrócić uwagę, że podobieństwo to, w rozumieniu Biskupa, jest realnym udziałem w tym, do czego jest się podobnym; Syn jest podobny do Ojca, czyli jest Mu równy. Natomiast we Wcieleniu druga Osoba Boska staje się, tak jak stworzenie. Syn Boży będąc pełnym obrazem, staje się obrazem według tego obrazu, czyli staje się człowiekiem.

Ojciec kocha w Synu swój obraz, jednocześnie w Synu kocha wszystko, co jest obrazem Syna, co oznacza, że miłość, jaką jest obdarowane stworzenie, jest tą samą miłością, którą Ojciec kocha Syna. Właśnie ta miłość poprzez Syna w Duchu Świętym jest przekazywana człowiekowi i reszcie stworzenia. W przekonaniu Grzegorza celem działań wynikających z miłości jest jedność: zarówno w Trójcy, jak i jedność z Bogiem wszystkiego, co jest od Niego różne. Swoje nauczanie opiera on na przekonaniu, że każde działanie Boga jest działaniem Trzech, w jedności z Nich wypływającej, jest to jedno działanie w Nich i jeden Boży zamiar wobec stworzenia: Bóg pragnie jedności ze swoim

${ }^{21}$ Por. In illud: Tunc ipse filius, GNO 3/2, 23, PG 44, 1321B.

${ }^{22}$ De perfectione Christiana ad Olympium monachum 49, ed. W. Jaeger, GNO 8/1, 194-195, tłum. J. Naumowicz: $O$ doskonatości, BOK 15, 75. Koncepcja czlowieka greckich Ojców Kościola opiera się na powszechnym założeniu, że czlowiek stworzony jest nie tyle na obraz i podobieństwo

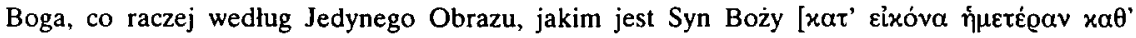
ópoiwoıv] (Rdz 1, 26 wg Septuaginty, ed. A. Rahlfs, Stuttgart 1935, repr. 1971).

${ }^{23}$ Por. De hominis opificio 3-5, PG 44, 133C-137C, thum. Sinko, dz. cyt., s. 64-70. 
stworzeniem. Właśnie w Chrystusie, Synu Bożym odczytujemy pragnienie jedności Boga z czlowiekiem. Pragnienie to wypływa z miłości, która chce być przekazywana, i ona właśnie jest podstawą istnienia świata. Biskup Nyssy na potwierdzenie swoich wniosków przywołuje słowa Syna Bożego, Jezusa Chrystusa: „Jak Ty, Ojcze, we Mnie, a Ja w Tobie, [spraw] aby i oni stanowili w Nas jedno" (J 17, 21) ${ }^{24}$. Bóg pragnie, by powołane do samodzielnego istnienia stworzenia w sposób wolny, czyli z miłości do Boga, pragnęły jedności z Nim. Jest to pierwszy powód, dla którego Syn stał się czlowiekiem. Jest to pełne zaangażowania działanie wobec człowieka i jego świata po to, by zjednoczyć całe stworzenie z Bogiem. Grzegorz jest głęboko przekonany, że Bóg jest w stanie podjąć wszelkie działania, by Jego pragnienie jedności mogło być zrealizowane. Syn Boży, poprzez swoje dzieło Wcielenia, „czyniąc swoją jedność [z Ojcem] w nas, On, który jest w Ojcu, w efekcie jednoczy nas z tym samym Ojcem"25. Jak Bóg przekazuje stworzeniu swoją miłość przez Syna, tak samo poprzez Syna dokonuje się zjednoczenie stworzenia z Bogiem. Celem tego działania jest obdarowanie świata wszystkim, co jest potrzebne do jego istnienia $i$ to istnienia autonomicznego $i$ wolnego wobec swego Stworzyciela. Biskup Nyssy stwierdza, że pełnię dóbr, jaką Bóg przekazuje człowiekowi, a przez niego reszcie stworzenia, obrazują słowa Jezusa: "Chwałę, którą mi dałeś, ja dałem im" (J 21, 22) i dopowiada, iż Chrystus przekonuje, że chwała dana człowiekowi jest po to, by ,jedność dana Mi poprzez Ducha Świętego, mogła być przeze Mnie wam [czyli ludziom] przekazana" 26. Największym zatem szczęściem człowieka jest jedność z Bogiem i to jest jego chwałą.

W sposób schematyczny rozumowanie sw. Grzegorza można przedstawić następująco: Bóg objawia się nam jako Bóg, który jest Miłością; jest to wzajemna miłość Ojca i Syna i Ducha Świętego. Wzajemna miłość trzech Osób Trójcy jest podstawą ich jedności. Miłość Boga objawia się w jednym działaniu wobec całego stworzenia. Jednocześnie jest w Bogu, wynikające z miłości, pragnienie udzielania „swojej chwały" 27 powołanemu do istnienia stworzeniu. Stworzenie to istnieje autonomicznie, jako całkowicie odrębny od Boga twór, ale o którym nie da się pomyśleć bez relacji do Stwórcy. W jego istotę wtopione jest pragnienie jedności z Bogiem. Celem działań Boga wobec stworzenia jest przeniesienie jedności Trzech, poprzez Syna Bożego w Duchu Świętym, na człowieka, a przez niego na całe stworzenie. Schemat rozumowania św. Grzegorza potwierdzają słowa, które dotyczą celu, dla jakiego istnieje całe stworzenie:

\footnotetext{
${ }^{24}$ Por. In illud: Tunc ipse filius, GNO 3/2, 21, PG 44, $1320 \mathrm{C}$.

${ }^{25}$ Tamize.

${ }^{26}$ Tamże, GNO 3/2, 22, PG 44, 1320D-1321A.

27 Tamże.
} 
„Ciało [człowiek] powinno stać się takim jak Słowo poprzez zjednoczenie z Nim; skutkiem tego [zjednoczenia] ciało otrzymuje to, co Słowo mialo przed stworzeniem świata ${ }^{28}$.

Pragnieniem Boga jest, by człowiek, a przez niego cały kosmos, zostali włączeni w jedność, jaka jest w Nim. Zanim świat zaistniał, jest w Ojcu pragnienie zjednoczenia ze swoim stworzeniem poprzez Syna, jednością sprawianą przez Ducha Swiętego. Z tego względu Syn Boży stał się człowiekiem. Dzięki Niemu wszyscy ludzie mają możliwość zjednoczenia się z Bogiem Ojcem.

Przedstawiony schemat nauczania Grzegorza o jedności Boga ze swoim stworzeniem daje się pomyśleć, bez uwzględniania upadku człowieka. W jego teologii można odczytać przekonanie, że Bóg stałby się człowiekiem niezależnie od ludzkiego odejścia. Syn ze względu na sam fakt powołania do istnienia różnych od Boga stworzeń, poddaje siebie woli Ojca i ostatecznie staje się stworzeniem. $Z$ drugiej strony wart jest podkreślenia fakt, że teologia Wschodu widziała we wcieleniu Syna Bożego akt dobrowolnego uniżenia. Syn poddaje siebie woli Ojca, ze względu na powołane do istnienia stworzenie. Można stwierdzić, że dobrowolne zniżenie się Syna poprzez przyjęcie ludzkiej natury, jest wpisane w obraz Boga ${ }^{29}$, ponieważ jedynie Syn jest prawdziwym obrazem Ojca. Natomiast człowiek jest obrazem Syna. Możemy powiedzieć, że nauczanie Grzegorza pozwala widzieć wszechmoc Boga jako tę, która ze względu na dobro stworzeń ogranicza samą siebie w Synu. To ograniczenie rozumiane jest jako uniżenie i jako takie było szczególnie przeżywane w duchowości Wschodu. Jeżeli - prowadząc dalej rozumowanie - cały wszechświat został powołany do istnienia według obrazu, jakim jest Syn, to uniżenie Syna jest u podstaw aktu stworzenia. Można pójść jeszcze dalej w rozpoznaniu nauczania Biskupa Nyssy i stwierdzić, że jak nie można pomyśleć istnienia świata bez relacji do Boga, tak nie można pomyśleć tego świata bez istniejącego w nim Wcielenia, a nawet bez uniżenia, jakie musialo się dokonać, by było możliwe Wcielenie. Analizując ten aspekt teologii Grzegorza możemy zobaczyć Boga jako tego, który w Synu wyzbył się wszystkiego dla stworzenia, by przez Niego przyjąć je do swojej jedności ${ }^{30}$. Wyzbył się wszystkiego, bo tak chyba można określić rzeczywistość, w której wszechmocny Bóg przyjmuje na siebie wszystko, co dotyczy stworzenia.

Autor nasz przedstawiając pragnienie jedności Boga ze swoim stworzeniem odwołuje się do słów Jezusa $z$ Ewangelii św. Jana. Zostały one wypowiedziane

${ }^{28}$ Tamże, GNO 3/2, 22, PG 44, $1320 \mathrm{D}$.

${ }^{29}$ Por. W. Hryniewicz, Kenoza, EK VIII 1348-1349 (IV. W teologii prawoslawnej).

30 Ojcowie greccy wprowadzili termin przebóstwienie na określenie rzeczywistości ciąglego udzielania Boga swojemu stworzeniu. Nie jest to jednorazowo osiągalny stan, ale trwający proces, który sam w sobie nie jest celem, ale środkiem przybliżania się do Boga. Tak rozumiana rzeczywistość pozwala zobaczyć Boga jako tego, który nie jest inaczej, jak tylko „Bogiem z nami” (Mt 1,23). 
tuż przed męką na krzyżu i choć, ze względów analitycznych, przedstawiliśmy nauczanie Biskupa kapadockiego bez uwzględniania tego dzieła Boga dla człowieka, to $\mathrm{w}$ naszym przekonaniu, milcząca obecność pełnego uniżenia Boga z miłości do człowieka w tle naszych rozważań, jeszcze bardziej podkreśla wszechmoc Boga, który panuje poprzez dobrowolne uniżenie.

2. Staranie Boga o stworzenie. Biskup Nyssy w swoim nauczaniu przekonuje, że stan, jaki znamy teraz, i miejsce, z którego mówimy o wszechmocy Bożej, związane są z upadkiem człowieka. Warunki, w jakich obecnie znajduje się świat, wyznacza sytuacja zawinionego odejścia od Boga. Stworzony w lasce człowiek, w rozumieniu św. Grzegorza z Nyssy, poprzez grzech zniszczył podstawę swego istnienia ${ }^{31}$. To, że $w$ ogóle $w$ tej sytuacji człowiek istnieje jest niewyobrażalnym cudem ${ }^{32}$. Niezmienna wszechmoc Boża objawia się w jego rozumieniu jako ta, która daje istnienie człowiekowi, mimo że on przez swoje grzechy odcina się od źródła istnienia, jakim jest Bóg. Można nawet powiedzieć, że im bardziej człowiek nadużywa swojej wolności, tym bardziej Bóg kieruje ku niemu swoją miłość. Nie należy oczywiście rozumieć, że zło zwiększa Bożą miłość, ale że Bóg w swej niezmiennej miłości jeszcze bardziej trwa przy takim człowieku. Analizując działanie mocy Bożej Grzegorz stwierdza:

„moc zawsze pozostaje taka, jaka jest; ani nie zmienia się i ani nie staje się lepsza lub gorsza. Również, nie ma w mocy Bożej tendencji do ulepszania siebie ani nie ma skłonności do zmian ku gorszej kondycji. Raczej, moc Boża stale wylewa zbawienie na innych, i działa udzielając ocalenia sama nie doznając żadnego braku"33.

Wszechmoc Boga jako niezmienna i nienaruszalna nie doznaje nigdy żadnego uszczerbku, i nikt ani nic nie może jej zmienić. Jednocześnie niezmienność wszechmocy Bożej polega na ciągłej gotowości do obdarowywania zbawieniem, na pełnej gotowości uczynienia wszystkiego, co możliwe dla stworzeń, aż po przyjęcie wszelkich konsekwencji grzechu. Można powiedzieć, że stałość Boga to stała gotowość niesienia pomocy i ratunku. Biskup Nyssy w charakterystyczny dla siebie sposób przekonuje, że Boża wszechmoc w swoim działaniu jest zdeterminowana przez miłość. Bóg:

,[...] samą myślą stworzył wszystko i aktem swej woli powołal do bytu to, co nie istniało, lecz mimo to [...] wybrał do tego (odkupienia) okrężną drogę, przyjmując cielesną naturę, przez narodzenie wchodząc w życie i przechodząc wszystkie fazy

${ }^{31}$ Por. E. Kotkowska, Pomyśleć świat jako catość wedlug św. Grzegorza z Nyssy, Poznań 2003, 50-61.

${ }^{32}$ W nauczaniu Grzegorza z Nyssy Syn Boży: „[...] dla naszego dobra postanowil narodzić się pośród nas, którzyśmy utracili istnienie (podkreślenie autorki) przez nadużycie wolności, [po to] aby mógł przywrócić do istnienia wszystko, co je utracilo" (De vita Moysis 2, ed. J. Daniélou, SCh 1, 177, thum. H. Bednarek, w: A. Louth, Poczq̨iki mistyki chrześcijańskiej, Kraków 1997, 112.

${ }^{33}$ In illud: Tunc ipse filius, GNO 3/2, 7, PG 44, 1308A. 
rozwoju, kosztując potem śmierci i dopiero przez zmartwychwstanie dochodząc do celu"34.

Bóg pragnąc zachować wolność stworzeń wybiera te działania, które nie naruszają autonomii ich istnienia i wolności: nie działa arbitralnie, czy bezpośrednio, działa poprzez stworzenie. $Z$ tego względu przyjmuje na siebie nie tylko ludzką naturę, ale i konsekwencje upadku. Celem Bożego działania jest wyprowadzenie człowieka z sytuacji bez wyjścia. Wszechmoc Boga objawia się przez to, że mimo upadku człowieka, staje się On stworzeniem i „pojawia się w nędzy naszego obecnego życia" - po to, by być dla człowieka - ,jako wzór uczestniczenia w bóstwie" 35 . Cel wcielenia w nauczaniu Grzegorza jest stały: Syn Boży ukazuje człowiekowi, jak bardzo Boża miłość jest do niego skierowana i jak może realizować siebie w dążeniu do pełni ${ }^{36}$. Natomiast po grzechu człowieka, Bóg poprzez Wcielenie pokazuje, w jaki sposób może on tę utraconą miłość odzyskać. Tak wyraża się wierność Boga wobec swojego stworzenia, niezależnie od tego, w jakiej kondycji się ono znajduje. W Chrystusie ukazuje się niezmienne pragnienie jedności Boga ze swoimi stworzeniami, ponieważ na tym polega ich szczęście. W rozumieniu Grzegorza Bóg:

,[...] który wszystko dla siebie stworzył, woła i pociąga duszę [człowieka] do siebie jako do źródła szczęścia"37.

Jest to bardzo charakterystyczny rys teologii Biskupa Nyssy - Bóg jako wszechmocny oddziałuje na człowieka nie przymusem, ale siłą miłości. Ta przyzywająca miłość Boga nie narusza jednak wolności istnienia stworzeń, ale dostosowuje się do ich kondycji po to, by osiągnęły wszystko, co dla ich istnienia jest najlepsze. Zastanawiając się dalej nad celowością Bożych działań Grzegorz przekonuje:

„Co do celu zbawienia, mówi się, że Jednorodzony Syn Boga jest poddany Ojcu, ze względu na Jego upodobnienie się do ludzi" ${ }^{38}$.

Oznacza to, że zbawienie świata realizuje się w historii człowieka Jezusa z Nazaretu, który poddaje siebie woli Ojca. Z tego względu, w przekonaniu

${ }^{34}$ Oratio catechetica magna 15, PG 45, 43BC, PSP 14, 151. Sw. Grzegorz z Nazjanzu podejmuje ten sam problem w słowach: „Niech nikt jednak nie odważy się twierdzić, że Bóg nie mógl przybrać innej postaci, by nam się ukazać. Proszę sobie przypomnieć krzak gorejacy $(\mathrm{Wj} 3,6)$ i różne objawienia w postaci ludzkiej. Lecz jeżeli Bóg chciał usunąć wszelkie przyczyny potępienia za grzech przez uświęcenie w sobie każdego elementu naszej natury, to musial przyjąć ciało" (Epistula 101, SCh 208, 50-51, thum. J. Stahr, POK 15, 142).

${ }^{35}$ In illud: Tunc ipse filius GNO 3/2, 18, PG 44, 1316D.

${ }^{36}$ Por. S. Strękowski, Wcielenie Syna Bożego w utworach św. Gregorza z Nyssy, VoxP 20 (2000) t. 38-39, 199-212.

37 Dialogus de anima et resurrectione, PG 46, 97D, thum. W. Kania, PSP 14, 62.

38 In illud: Tunc ipse filius, GNO 3/2, 7, PG 44, 1308A. 
naszego Autora, Bóg, który stał się człowiekiem, musiał się zgodzić, że dotkną go wszelkie konsekwencje odejścia stworzeń od Boga. To właśnie niezgoda na zlo $\mathrm{z}$ jednej strony i zgoda na wolność stworzeń z drugiej strony, prowadzi w konsekwencji do zgody na doznawanie i przeżywanie skutków wszelkiego zła. Nie jest to bierna zgoda na istnienie grzechu, ale punkt wyjścia, by to zło przezwyciężyć: zniszczyć je nie poprzez arbitralny akt Bożej mocy, ale przez przemianę wszelkich złych skłonności w człowieku w kierunku dobra. Nawiązując do Pisma Swiętego nasz Ojciec Kościoła jest przekonany, że Chrystus:

„z powodu tego, co wycierpiał aż do śmierci, przez krótki czas był niższym od aniołów (Hbr 2, 6-9); i tych, którzy z racji grzechu stali się jakby cierniami, przez zbawcze dzialania swojej śmierci uczynił koroną dla samego siebie, przez swą mękę bowiem cierń przemienił w chwałę i cześé"39.

Zgodę Syna Bożego na takie zrealizowanie woli Ojca, które prowadzi do wyzwolenia czlowieka z niewoli grzechu, Grzegorz za św. Pawlem, nazywa poddaniem (íjotóoow) Syna Ojcu. Syn Boży poddaje siebie Ojcu jako stworzenie, natomiast w przekonaniu naszego Autora: „Podporządkowanie to nie ma miejsca w Bożej niezmiennej i stałej mocy"40. W człowieku Jezusie z Nazaretu wszystkim ludziom zostaje objawiona niezmienna wszechmoc Boga. W swoim bóstwie Syn jest równy Ojcu i dlatego nie poddaje siebie w boskiej naturze, poddanie natomiast realizuje się w naturze ludzkiej wcielonego Słowa. Ma ono dla ludzi moc zbawczą, ponieważ, jak przekonuje Biskup Nyssy: „Dla nas zbawienie zostało przyniesione poprzez poddanie"41 Syna Bożego Ojcu.

Należy się również zastanowić, dlaczego, według Grzegorza, dobrowolne poddanie się Syna woli Ojca aż po śmierć na krzyżu, przynosi całemu stworzeniu zbawienie? Celem poddania wcielonego Słowa jest przywrócenie jedności Boga ze swoim stworzeniem. Bóg nie może chcieć zjednoczenia z jakimkolwiek złem. Chrystus jest dla człowieka wzorem, jak w naturze ludzkiej należy walczyć z tym, co niezgodne z wolą Boga. On objawia człowiekowi, że ,poddanie się Bogu, to całkowite odizolowanie się od zła" ${ }^{, 42}$. Objawia to całym swoim życiem, a szczególnie w śmierci i zmartwychwstaniu. W Jezusie z Nazaretu Bóg rozpoczyna przemianę świata i $w$ ten sposób przynosi światu zbawienie. Chrystus staje się zaczątkiem przemiany stworzenia od wewnątrz. W Nim nie ma żadnej skłonności ku złu, Jego życie jest życiem według natury ludzkiej, zamierzonej przez Boga dla człowieka ${ }^{43}$. Dlatego poprzez Wcielenie, sam będąc stworzeniem, rozpoczyna poddawanie Bogu calego stworzenia, czyli

\footnotetext{
${ }^{39}$ De perfectione Christiana 72, GNO 8/1, 206, BOK 15, 82.

${ }^{40}$ In illud: Tunc ipse filius, GNO 3/2, 7, PG 44, 1308A.

41 Tamże, GNO 3/2, 27, PG 44, 1325 A.

42 Tamże, GNO 3/2, 16, PG 44, 1316A.

${ }^{43}$ Por. S. Longosz, Chrystologia Ojców Kapadockich, VoxP 17 (1997) t. 32-33, 166-176.
} 
przywraca jedność, jakiej Bóg Ojciec pragnie dla swoich stworzeń. Powyższe wnioski można podsumować słowami św. Grzegorza:

„To jest to, co mówimy o poddaniu Syna - jeżeli Chrystus w swoim ciele rzeczywiście jest poddany i zostało mu to dane, to On teraz działa tak, że w nas realizuje się łaska poddania"44.

Biskup rozważa tu dwa aspekty działania zbawczego. Od strony Boga działania odkupieńcze już się dokonały. Ojciec przyjąl poddanie Syna, który przez to dokonał odkupienia świata. Należy stwierdzić, że dzięki temu, iż Syn, w którym istnieje całe stworzenie, poddał stworzenie Ojcu w swojej ludzkiej naturze, to ostatecznie pokonal wszelkie zło. Dzięki temu dziełu uwidacznia się działanie, w którym „moc zła będzie zupełnie usunięta" ${ }^{45}$. Św. Grzegorz wyraża pełniej tę myśl w słowach: „o nasze [ludzi] zbawienie czynione są starania” "46. Bóg zawsze stara się o człowieka, by on również w swojej wolności poddał siebie Bogu, ale uzależnia swoje działania zbawcze w świecie od woli człowieka ${ }^{47}$. W Grzegorzowym nauczaniu być podobnym, to mieć udział w tym, do czego jest się podobnym. $Z$ tego też względu, jeżeli człowiek chce żyć na wzór Chrystusa, to musi być z Nim zjednoczony. Na bazie tego zjednoczenia wcielony Syn Boży działa w świecie. Stąd to nasz Ojciec Kościoła wyraża przekonanie, że Chrystus zmartwychwstały, czyli ten który poddał siebie Ojcu, działa w świecie we współpracy z człowiekiem:

„poprzez przyłączanie nas do siebie [...] Chrystus czyni siebie jednym ciałem z nami. Poprzez wszystko, co jest nasze i przez nas opiekuje się wszystkim"48.

Celem tego działania jest przywrócenie człowiekowi prawidłowych relacji ze Stwórcą i z resztą stworzenia. Bóg pragnie, by człowiek odzyskał pełnię wszystkich darów, jakie otrzymał w chwili powolania go do istnienia, i to pragnienie realizuje się przez ciągle Jego staranie się o człowieka. Jest to działanie, w którym Bóg siłą swej milości przyciąga do siebie, a które nie jest wolne od napięć. Stąd można je określić jako walkę o to, co dla stworzenia najlepsze. Walka ta toczy się przede wszystkim o to „aby się cofnęły szeregi nieprzyjaciól"49 człowieka i wszelkiego stworzenia. W tym działaniu żadne dzieło Boga nie jest wyłączone czy pominięte ${ }^{50}$. Ten proces, starania się Boga o czlowieka

\footnotetext{
${ }^{44}$ In illud: Tunc ipse filius, GNO 3/2,16, PG 44, 1316B.

45 Tamże, GNO 3/2, 27, PG 44, 1325AB.

46 Tamże, GNO 3/2, 7, PG 44, 1308A.

${ }^{47}$ Por. Kotkowska, dz. cyt., s. 34-47.

48 In illud: Tunc ipse filius, GNO 3/2, 20, PG 44, 1317D-1320A.

${ }^{49}$ Gregorius Nyssenus, De Oratione Dominica III 5, PG 44, 1160, tłum. W. Kania, VoxP 6 (1986) z. 11, 692 lub w: Modlitwa Pańska. Komentarze greckich Ojców Kościoła IV-V wieku, red. K. Bielawski, Kraków - Tyniec 1995, 59.

${ }^{50}$ Por. In illud: Tunc ipse filitu, GNO 3/2, 14, PG 44, 1313 A.
} 
wymaga współpracy człowieka. Dlatego też to poddanie jest przez Biskupa Nyssy rozumiane jako przyjęcie w miłości tego, co najlepsze. Rzeczywistość ta zrealizuje się w ostatecznym spełnieniu dziejów, gdy cała ludzkość będzie w pełni poddana Bogu. Zgodnie ze słowami św. Grzegorza:

\begin{abstract}
„Wtedy będziemy poddani Jemu, ale nie należy tego rozumieć jako jakiś rodzaj stużalczej pokory. Nasze poddanie to królestwo, składające się z nienaruszalności i szczęścia żyjącego w nas samych; takie jest znaczenie Pạłowej nauki o poddaniu Bogu. Chrystus sam ulepsza nasze dobro w nas, i tworzy w nas to, co jest mile $\mathrm{Jemu}^{51}$.
\end{abstract}

Biskup Nyssy stwierdza, iż należy poddać się Bogu, ale nie na sposób służalczego poddania. Trzeba w wolności wybrać to, co lepsze, czyli najwyższe dobro, jakim jest Bóg; by to zadanie mógł człowiek wykonać, wszechmogący Bóg obdarował go wolnością. Dzięki niej czlowiek może odpowiedzieć Bogu tak, by zrealizować Boże pragnienie jedności z Nim.

$* * *$

Sw. Grzegorz z Nyssy w swoim nauczaniu jest przedstawicielem zadziwiającej zgodności filozofii, teologii i nauk szczegółowych. Jego całościowa wizja relacji, jakie zachodzą pomiędzy niezmiennym Bogiem, a Jego zmiennym stworzeniem, pozwala zobaczyć wszechmoc Najwyższego w wielu aspektach i perspektywach. Dla współczesnych badań teologicznych wydaje się ważne ukazanie, że przedstawiciel teologii IV wieku myśli o wszechmocy Bożej jako o tej, która działa w świecie poprzez uniżenie. Grzegorz przekonuje, iż Stwórca swoją nieograniczoną moc objawia przede wszystkim poprzez samoograniczenie we wcieleniu. Nie rozważa on tego problemu jako właściwego teologii $(\theta \varepsilon o \lambda o \gamma i \alpha)$, ale jako przedmiot badań wchodzący w zakres ekonomii

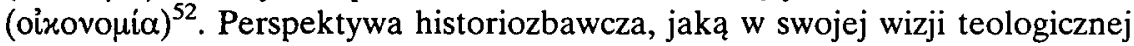
przyjmuje ten Ojciec Kościoła, pozwala mu interpretować dzieło Syna Bożego, który $z$ miłości do Ojca stał się stworzeniem i przyjął na siebie wszelkie konsekwencje tego czynu, jako dynamiczne wzajemne relacje pomiędzy Bogiem a stworzeniem. Bóg Ojciec w swym miłosnym pragnieniu jedności z Synem i Duchem Świętym, pragnie poprzez Nich miłości i jedności ze swoim stworzeniem: Bóg zabiega o stworzenie, ciągle się o nie troszczy. To ciągłe trwanie w tym staraniu jest, w pewnym sensie, Jego niezmiennością. Jest to niezmienność pełna dynamizmu i napięć, która wyraża się poprzez ciągłe miłosne wychodzenie ku stworzeniu: im bardziej stworzenie potrzebuje miłości Boga, tym bardziej On je tą miłością obdarza. Największym wyrazem tej niezmiennej

\footnotetext{
51 Tamże, GNO 3/2, 28, PG 44, $1325 \mathrm{C}$.

$\$ 2$ Por. przypis 16.
} 
miłości Boga do stworzenia jest dzieło Syna Bożego, który poprzez wcielenie „wchodzi" we wszystkie powiązania i zależności tego świata. Bóg stając się czlowiekiem nie przestaje być jego stwórcą i archetypem wszelkiego stworzenia. Jest to podstawowy fakt, na którym wydaje się, iż powinna się opierać obecnie powstająca metafizyka relacji. Św. Grzegorz z Nyssy poprzez swoje nauczanie daje podstawy do ponownej reinterpretacji relacji, jakie zachodzą pomiędzy wszechmocą Bożą a ludzką wolnością.

Człowiek poznaje niezmiennego Boga dzięki dziełu Syna, a szczególnie w Jego śmierci i zmartwychwstaniu. Jest to dzieło Syna Bożego zapoczątkowujące ostateczną przemianę świata, który potrzebuje odnowienia. Patrząc na dzieło Syna Bożego, w głębszej analizie nauczania Biskupa Nyssy, jawi się ono jako moment konstytutywny dla istnienia świata. Przyjmując Grzegorzową perspektywę historiozbawczą należy stwierdzić, ze czyn Chrystusa, dokonany w konkretnym czasie, jest ontologicznie pierwszy i wynika $z$ niezmiennej Bożej milości, która pragnie wolnej zgody stworzenia na bycie $\mathrm{z} \mathrm{Nim}{ }^{53}$.

Wszechmocny Bóg, po upadku stworzenia, nie przywraca poddania sobie świata stworzonego poprzez arbitralne rozkazy, ale poprzez przyciągającą siłę przykładu i miłości. Syn Boży poddał siebie Ojcu w swej ludzkiej naturze nie naruszając niezmiennej mocy Bożej w sobie. W Nim, który poprzez krzyż przyłącza do siebie całe stworzenie, według św. Grzegorza z Nyssy, wszystko będzie poddane Bogu według słów św. Pawła Apostoła: „Syn zostanie poddany (ย் we wszystkich" (1Kor 15, 28). Nasz Ojciec Kościoła przekonuje, iż nieskonczone uniżenie Syna Bożego, poprzez niezasłużone cierpienie i śmierć, jest największym dowodem Jego boskości i mocy, która manifestuje się w zmartwychwstaniu. Moc Boża ze względu na ludzką wolność przymusza i przyciąga „tylko" siłą swej niezmierzonej i niezmiennej miłości i w ten sposób przemienia całe stworzenie ku jego wypełnieniu w Bogu.

\section{ST GREGORY OF NYSSA'S TEACHING ON GOD'S OMNIPOTENCE' BASED ON THE TREATISE IN ILLUD: TUNC IPSE FILIUS}

\section{(Summary)}

Analysing the work of St Gregory of Nyssa, in the first approximation we can say that he is a typical representative of his age. In the theology of the $4^{\text {th }}$ century the power of God as the absolute ruler was emphasized more than his other attributes,

\footnotetext{
${ }^{53}$ Por. Węcławski, dz. cyt., s. 114-121.
} 
so the image of God did not show him as the One who reigns through humility. In this regard, it is worthwhile to draw attention to a small, polemic traetise In illud: Tunc ipse filius of St Gregory, in which his understanding of God's omnipotence receives a deeper dimension that appeals to the modern man. In his work, this Father of the Church comments on one verse from the Letter of St Paul to the Corinthians: "And when everything is subjected to him, then the Son himself will be subject in his turn to the One who subjected all things to him, so that God may be all in all" (1 Cor 15,$28 ; \mathrm{KJ})$. The problem which preoccupied Gregory of Nyssa, was the incorrect opinion or heresy of Arius and his followers. According to them, the Son is subjected to God, by the rule of creation, so He cannot be equal to God the Father and, in this way, He is not God. One from the crown arguments, which the Arians used were St. Paul's words from his Letter to the Corinthians. However, the Bishop of Nyssa shows, that exactly this quotation, from the historical-salvific perspective, emphasizes the divinity of Christ. He portrays to us the Son who is subjected to God's vivifying power and the Father who receives the Son's subjection in His human nature. So, in this way, God is omnipotent on the cross, as a humble man. The image of God, which emerges from Gregory's theology, allows us to include his voice into present discussion of God's omnipotence and man's free will. 